\title{
In emerging economies, the effect of excessive credit growth and non - performing loans on banking crisis
}

\section{El efecto del crecimiento excesivo del crédito y los préstamos no redituables en la crisis bancaria de las economías emergentes}

\author{
K. Batu Tunay ${ }^{1}$, Hasan F. Yüceyılmaz ${ }^{2 *}$, Ahmet Çilesiz ${ }^{3}$ \\ ${ }^{1}$ Marmara University, Turkey \\ ${ }^{2}$ Banker, Turkey \\ ${ }^{3}$ Financial Adviser, Turkey
}

Received September 26, 2018; accepted March 27, 2019

Available online October 21, 2019

\begin{abstract}
Crediting in the banking sector plays an important role in developed and developing countries, which have built their financial system more on banking rather than capital markets. For this reason, it is monitored continuously by public authorities and measures are taken to control credit supply in rapid credit increases. In addition, strict provisioning rules for non-performing credits are under practice for non-performing loans. It is well known that in emerging markets strong credit growth in a given period is likely to end up with a financial crisis.

In this study, the effects of credit-based variables on bank crises in the emerging 23 economies were investigated. In particular, the effects of credits and non-performing loans on crises are focussed. Additionally, the bank system-specific and macroeconomic control variables are included in the analysis. Findings show that private sector lending by banks and non-performing loans reflecting credit risk do not explain bank crises. Instead, it has been determined that the provisions for non-performing loans by banks and the credit gap that is considered to reflect the systemic risk in the banking system affect crises.
\end{abstract}

JEL code: $\mathrm{G} 01, \mathrm{G} 21, \mathrm{C} 33$

Keywords: Banking crisis; Credit growth; Credit gap; Non-performing loans; Systemic risk

${ }^{1}$ School of Banking and Insurance, Capital Markets Department.

${ }^{2}$ Ziraat Bank.

* Corresponding author.

E-mail address: hyuceyilmaz@gmail.com (H.F. Yüceyılmaz).

Peer Review under the responsibility of Universidad Nacional Autónoma de México. 


\section{Resumen}

La concesión de créditos en el sector bancario desempeña un papel importante en los países desarrollados y en vías de desarrollo, que han basado su sistema financiero más en las operaciones bancarias que en los mercados de capital. Por esta razón, las autoridades públicas la supervisan constantemente y se toman medidas para controlar la oferta crediticia en aumentos rápidos de crédito. Además, a los préstamos no redituables se les aplican estrictas reglas de provisión para créditos no redituables. Es bien sabido que en los mercados emergentes es probable que un periodo de fuerte crecimiento del crédito termine con una crisis financiera.

En este estudio, se han investigado los efectos de variables basadas en el crédito en las crisis bancarias de 23 economías emergentes. En particular, el estudio se centra en los efectos de los

créditos y préstamos no redituables durante las crisis. Asimismo, en el análisis se incluyen variables de control macroeconómico y específicas del sistema bancario. Los hallazgos muestran que los préstamos del sector privado por parte de los bancos y los préstamos no redituables que reflejan el riesgo crediticio no explican las crisis bancarias. En cambio, se ha determinado que sí afectan a las crisis las provisiones para préstamos no redituables de los bancos y la brecha crediticia que se considera que refleja el riesgo sistémico en el sistema bancario.

Código JEL: G01, G21, C33

Palabras clave: Crisis bancaria; Crecimiento crediticio; Brecha crediticia; Créditos no redituables; Riesgo sistémico

\section{Introduction}

The term 'Emerging economies or markets is a concept that characterizes countries that invest in developing production factors, move away from traditional economic structures based on the export of agricultural products and raw materials, rapidly industrialize, adopt a free market economy or mixed economy, and want to improve the quality of life of their people. While the per capita income levels of such countries are well below those of industrialized countries, their annual growth rates are well above those of industrialized countries. Often, social changes are rapid, and at the heart of them are efforts to solve structural economic problems. Due to the inadequate resources needed for development, the indebtedness rates are high, especially in the public sector, and there is a serious need for foreign capital. Despite the need for fixed capital investments for sustainable growth and development, it is generally seen that there are speculative capital inflows. Such countries are attractive for portfolio investments, as they offer high yield opportunities due to rapid growth and increased financing requirements, and most of the foreign investments are short term.

The fact that increased financing demands met quickly by means of capital flows leads to credit growth above the past trends of the country. This situation becomes unsustainable with 
the economic slowdown in the course of time and narrows the supply of credit and causing financial crises from time to time. IMF's 2004 report states that although some of the credit growth leads to financial deepening, Credit growth in emerging economies linked to a financial crisis is as high as $75 \%$. On the other hand, rapid credit growth cannot be considered as the mother of all evil in all circumstances. We have witnessed at the beginning of the 2008 global financial crisis that the credit supply has been expanded by the public through public guarantee programmes.

During this period, it has been seen in many countries that financial authorities have either enlarged, extended coverage or launched new guarantee programmes and/or used these programmes in the context of effective counter-cyclical financial measures in order to avoid the rapid economic slowdown.

In the light of the above findings, the hypotheses searched in this study are that the excessive credit growth in emerging market economies increases non-performing loans and strengthens the possibility of the bank crisis. After examining the findings of similar empirical studies, the effects of credit growth and non-performing loans in 23 emerging economies and their potential for triggering bank crises have been analyzed econometrically.

The dynamic panel probit method has been used as the analysis tool. This method is a more powerful analysis tool than the alternatives because it allows the panel probit model to incorporate the dynamic effects of crisis probabilities. The related literature is studied in the second, the analysis and modelling take place in the third part.

\section{Theoretical Background}

Crediting has a crucial role in economies. The inadequacy of credit means that the economic activity is restricted and the long-term development of the country is weak. However, rapid credit growth can also damage the economy and lead to a financial crisis. It is possible to find a significant number of studies in the literature on the problems caused by excessive credit growth. (Gourinches 2001) reports that the likelihood of a banking crisis has risen rapidly after rapid credit growth periods and that the greater the credit growth, the higher the likelihood of a crisis.

DellAriccia and Marquez (2006) suggest that banks have lowered their lending standards during periods of rapid credit growth, which in turn worsened the credit portfolio and the banking system became vulnerable to financial pressure as downside risks to the economy arise. Jorda, et al (2011), Davis, et al (2016) suggest that excessive credit growth is the best indicator of the financial crisis and that this relationship is strengthened when it is combined with the increasing current account deficit. In a similar study, Schularick and Taylor (2009) have argued that successive economic instability is caused by a bad credit growth period. They 
argue that the main reason for this is probably the result of the financial system's operational management and its regulatory failures. Levine (2005) states that credit can rapidly grow mainly in financial deepening, in normal upswings and in excessive cyclical fluctuations.

Elekdag and $\mathrm{Wu}$ (2013), show that balance sheets of banks and companies deteriorate during excessive credit growth, overheating in the economy takes place together with large capital flows, the current account deficit increases, asset prices show an upward trend and domestic demand is strong. Secondly, while excessive credit is associated with large capital flows, international interest rates (representing global liquidity) generally remain horizontal. This shows that there may be a relationship between the two in developing markets. Thirdly, excessive credit growth seems to be related to the loose monetary policy in the country. While international interest rates are flat, the benchmark interest rate in the domestic market seems to be low in the pre-crisis period before the credit growth reaches its peak.

In literature, mainly two sources come to the front for increasing non-performing loans (NPLs) as bank-specific and country-specific which might also be called external or bank originated factors. For bank-specific factors; Keeton and Morris (1987) discussed the "moral hazard" problem and argued that banks with relatively low capital increased the riskiness of their loan portfolio, misguided by moral hazard incentives, which in turn might result in higher non-performing loans on average in the future. They showed that banks with relatively low equity-to-assets ratio suffered excessively from losses in the group.

Generally speaking, banks' appetite to take more risks in the form of excessive risk- taking resulted in higher losses. This finding was also supported by Salas and Saurina (2002) and Jimenez and Saurina (2005). As to the macroeconomic conditions, the debt servicing capacity of borrowers usually improves if there is higher real GDP growth in the economy. An economic slowdown will generally bring an increase in NPL level, unemployment rises and borrowers face greater difficulties in debt servicing. (Salas and Suarina, 2002; Ranjan and Dhal, 2003; Fofack, 2005 and Jimenez and Saurina, 2006).

Louzis et al. (2010), estimated the factors that affect NPLs for each loan category (mortgage, business, and consumer) separately. They concluded that NPLs could be explained by macro variables and the quality of management. Beck et al. (2015) found that GDP growth, share prices, interest rates, and the exchange rate are the most significant factors affecting NPLs. Messai (2013) cited that improving macroeconomic conditions reduce NPLs. and found that on top of GDP growth, ROA has a negative effect on NPLs. Ghosh (2015) concluded that poor credit quality, liquidity risk, inefficiency cost, larger capitalization and the size of the banking industry as well as unemployment, inflation, and public debt are the variables related to NPL increases. Ozili (2015) addressed the question of the interaction between non-performing loans and the stage of the business cycle. When so much at risk in the economic growth, regulation authorities naturally increase their efforts to curb the prolonged excessive 
credit growth in order to minimize the damages that might be created. In this perspective, one of the most important risk indicators used is called credit gap. Bank for International Settlements (2014) describes the credit-to-GDP gap ("credit gap") as the difference between the credit-to-GDP ratio and its long-term trend. Many studies show that it is a single early indicator of a systemic banking crisis.

Therefore, it is used in the benchmark buffer guide for the counter cyclical capital buffers (CCyB) as recommended by the European Systemic Risk Board (2017).

\section{Econometrical analysis and findings}

Modelling and analysis method

In the analysis of linear panel data models, the fixed effects estimator is generally used because of its simple and easy to understand structure. In this context, methods such as least squares or instrumental variables provide consistent estimates controlling unobserved heterogeneity in panel data sets which contain large cross-section but small-time dimensions.

However, in non-linear models with errors such as probit, the situation is much more different. The constant effects estimator cannot be used for the estimation of a panel data set containing a binary dependent variable. Because of the assumptions, such an analysis is based on random effects estimator will not also be appropriate. (see Arellano, 2003 for details).

Many economic and financial relationships are dynamic. Dynamic panel data models allow researchers to better analyze the core dynamic structures and interactions of the relationships. In these models, the addition of the delays of the dependent variable to the right of the equation as additional explanatory variables provides the opportunity to observe the dynamic effects and thus it is possible to observe the past effects as well as the immediate effects on the variables. Due to the mentioned advantages, the popularity of dynamic models in applied economics and finance is increasing. This is true for panel data sets based on binary dependent variables.

The main feature of dynamic panel data models is that they contain two sources of persistence over time. These; autocorrelation which caused by due to delays of dependent variable among exogenous variables and individual effects reflecting heterogeneity between individuals or cross-sections (Baltagi and Kao, 2000, p. 34).

It is well known that when the number of cross-sections or individuals is high but the period of time is short in micro panels, the fixed effects estimator is biased and inconsistent. (Baltagi and Kao, 2000: 35). Random effect GLS estimator is not also suitable for the analysis of data with dynamic characteristics, as it produces biased results. Although the approach of Anderson and Hsiao (1982) produced consistent results compared to the previous two methods, the effectiveness of parameter estimation was not always high (Baltagi, 2005, p.136). 
Simulation studies showed that dynamic panel data models based on GMM estimators do not have these disadvantages (Baltagi and Kao, 2000: 35-36).

GMM estimators adapted to dynamic panel data analysis (eg, Arellano and Bond, 1991; Arellano and Bover, 1995; Blundell and Bond, 1998), are based on relatively weak auxiliary assumptions about the exogeneity of the covariate process, heterogeneity and the properties of the error term processes (Blundell et al., 2000, p.53). In order to eliminate persistently unobserved heterogeneity, The standard approach is to take the first- difference of the equation and to use the lags of the endogenous variables in first differences as both exogeneous variables and instrumental variable (Blundell et al., 2000, p.54). However, in simulation studies, in the dynamic panel data models where the series were sequentially connected and the time-size observations were relatively small, it was determined that the standard GMM estimator was biased and poor precision.

As a result of Arellano and Bover (1995), Blundell and Bond (1998), the system GMM estimator is improved and is much more successful in terms of these problems. The system GMM estimator overcame the aforementioned problems by relatively softening the constraints in the initial condition process. Simulations showed that the system estimator was significantly more effective than the standard GMM estimator. (For a detailed discussion, see Blundell et al. 2000).

Dynamic panel data models, especially those based on the system GMM estimator, are not suitable for analyzing binary endogenous variables in binary structure despite all their advantages. However, it is doubtless that many important variables in the binary structure, such as crises and stagnations, have dynamic effects and the lack of consideration of these effects in the analysis will be a major deficiency. In this context, dynamic panel probit models stand out as an alternative method. Although the main idea is similar to conventional dynamic panel data models, they are significantly different from them as estimation methodology. However, there are usually two problems in modeling the dynamic effects in such models. The first is that the unobserved individual heterogeneity is correlated, and the other is that the idiosyncratic shocks are correlated. These problems come from the state dependence between the dependent variable and its lags.

In fact, in panel data econometrics, it is a long time matter to define the state dependence of an individual's choice based on unobservable heterogeneity. It is highly probable that a specific individual in the sample will exhibit a $t$ behavior at the time $t+1$.

This effect is called state dependency and makes the model inconsistent when it comes to a standard panel probit model. In this context, when unit-specific impacts are ignored, estimates may be biased. In the literature, the problem is usually solved by including a time-invariant error term in the model. However, this term may be correlated with initial conditions and, ultimately with the endogenous variable, leading to a problem called initial condition problem (Heckman, 1981, Ehreke et al., 2016). 
Heckman (1981) stated that the performance of Maximum Likelihood (ML) estimates of probit models including the delays of the dependent variable was poor for the reasons explained above. However, this is not a surprising result because similar problems are observed in linear autoregressive models. In this respect, the only difference between dynamic binary choice models and linear dynamic models is in terms of sampling distributions (Arellano, 2003).

The dynamic panel probit approach is unaffected by these problems, as it captures heterogeneity by including time-constant random effects to the conditional mean functions because the model parameters are estimated by the Maximum Likelihood (ML) estimator (Kano, 2013, Liesenfeld et al. 2007).

However, the Heckman estimator will become inconsistent if the error terms are autocorrelated. The most recently developed maximum simulated likelihood (MSL) estimator has overcome this problem of inconsistency (Kano, 2013, Ehreke et al., 2016). After Keane (1994) and Hyslop's (1999) pioneering work, Keane and Sauer (2009, 2010) developed simulation algorithms.

In the literature, empirical studies with these models are extremely low compared to those performed with dynamic panel data models. However, studies show that the forecast accuracy of dynamic panel probit models is high. For example, Antunes et al. $(2016,2018)$ showed that the forecast performance of early warning models performed with these models was significantly higher. In terms of determining the dynamic effects in the analyzed data set, the forecast power is much higher than the similar ones in the static structure. In the light of these explanations, dynamic panel probit method has been preferred since it allows dynamic analysis of a binary dependent variable in a binary structure such as bank crisis, as well as it allows to make more efficient and unbiased forecasts.

Researchers conducting empirical studies based on panel data sets often want to define a shadow or binary dependent variable $\left(\mathrm{y}_{\mathrm{it}}\right)$ as a function of its own delays $\left(\mathrm{y}_{\mathrm{i}, \mathrm{t}-\mathrm{1}}\right)$. Thus, the answer is sought as to whether the dependent variable is affected by its past movements.

Banking crises are such a variable and can also be explained as a function of its own delays. Therefore, a dynamic logit and/or probit model are required for analysis.

When a dynamic model is established, the dependent variable will be correlated to its own past values due to unobserved heterogeneity. If these delays are considered as exogenous inconsistent estimators, then the initial conditions problem will come into play. However, it is unclear which one of the above-mentioned estimation approaches is more successful against such problems that may occur in the estimation process and may decrease the prediction efficiency. Studies, in this area, are insufficient based on small and large samples. Miranda (2007) determined that Heckman's method produces estimates of low and high sensitivity bias compared to other two methods. The Heckman method is also satisfactory in the calculation of confidence intervals and other methods can give extremely bad results especially when the dependent variable is highly correlated with its past values. 
The general structure of the dynamic probit model (Heckit), which forms the basis of Heckman's (1981) method, can be shown as follows:

$$
\begin{aligned}
& y_{i t}^{*}=\gamma y_{i, t-1}+\beta x_{i t}+u_{i}+\varepsilon_{i t} \\
& y_{i 0}^{*}=\theta z_{i t}+\delta u_{i}+\eta_{i t}
\end{aligned}
$$

In this system of equilibrium, $\mathrm{y}_{\mathrm{it}}{ }^{*}(\mathrm{i}=1, \ldots, \mathrm{N} ; \mathrm{t}=2, \ldots, \mathrm{T})$ is latent which means that it a dependent variable that cannot be directly observed. The observed binary variable, $\mathrm{y}_{\mathrm{it}}$ is assumed to comply with the following assumption:

$$
y_{i t}=\left\{\begin{array}{l}
y_{i t}^{*} \geq 0 \Rightarrow 1 \\
y_{i t}^{*}<0 \Rightarrow 0
\end{array}\right.
$$

$\mathrm{x}_{\mathrm{it}}$ independent variables are arbitrary independent instrumental variables vectors, $\mathrm{u}_{\mathrm{i}}$ is unobserved individual-specific random effects. $\varepsilon_{\mathrm{it}}$ and $\eta_{\mathrm{it}}$ are error terms that are assumed to be distributed as $\mathrm{N}(0,1)$ and are assumed not to be serially correlated. The correlation between $\mathrm{y}_{\mathrm{it}}{ }^{*}$ and $\mathrm{y}_{\mathrm{i} 0}{ }^{*}$ is denoted by $\mathrm{Q}$ and is calculated as follows:

$$
\rho=\frac{\delta}{\sqrt{2\left(\delta^{2}+1\right)}}
$$

Equations (1) and (2) are estimated together as a system. One of the maximum likelihood and the ML + Gauss-Hermite quadrature or the Maximum Simulated Likelihood Estimator can be used in the forecasting process.

In our study, banking crisis ( crisis $_{\mathrm{it}}$ ) is defined as a shadow variable that takes a zero-time zero value when the crisis occurs for country $\mathrm{i}(\mathrm{i}=1, \ldots, \mathrm{n})$ and time $\mathrm{t}(\mathrm{t}=1, \ldots, \mathrm{T})$. This variable, except for their own delays, is considered to be influenced fundamentally by credits to private sector $\left(\mathrm{crd}_{\mathrm{it}}\right)$, non-performing loans $\left(\mathrm{npl}_{\mathrm{it}}\right)$ and by provisions for non-performing loans ( $\left.\mathrm{pnpl}_{\mathrm{it}}\right)$.

It is envisaged that the excessive credit growth will increase the non-performing loans and both direct and non-performing credits will raise the possibility of a banking crisis. It is believed that there is a positive relationship between these variables and bank crises. On the other hand, the provisions for non-performing loans are assumed to increase the robustness of banks against credit risk. Therefore, this variable is predicted to have a negative relationship with the banking crises. 
After the 2008 global financial crisis, the systemic dimension of banking crises gained importance and the importance of measuring systemic risk has increased. In this framework, BIS has developed a credit-to-GDP gap $\left(\operatorname{crdgap}_{\mathrm{it}}\right)$ as a systemic risk measure. Therefore, the variable is added to the model as a measure of systemic risk and it is accepted that the effect on banking crises will be positive. On the other hand, under the Basel Agreement, capital adequacy limits are also applied to increase the resilience of the banking sector against crises. In this context, the mandatory or regulatory capital (regcap ${ }_{i t}$ ) ratio is analyzed in the model.

Assuming that the increase of the mandatory capital ratio will increase the stability of the banks and decrease the probability of the crisis in the system, it is accepted that the relationship with the crisis will be negative. In addition, control variables that reflect the nature of the economy and the conditions of the related country's banking market are included in the model. Concentration ratio (concit) and Boone indicator (Booneit) are modelled as sector-specific variables that reflect the structure of the banking market and competitive conditions. The $\mathrm{z}$ score (zit) in the model reflects the financial strength of the banks. The findings of studies on the level of concentration and the effects of competition on banking crises in the literature show differences. Therefore, no preliminary judgement has been made as to how these variables could affect crises. However, it is predicted that the $\mathrm{z}$ score will have a negative relationship with the crises. The inflation rate $\left(\inf _{\mathrm{it}}\right)$, economic growth rate $\left(\mathrm{grw}_{\mathrm{it}}\right)$ and current account balance $\left(\mathrm{ca}_{\mathrm{it}}\right)$ are considered as variables reflecting macroeconomic conditions.

Although the effects of inflation on the banking crisis cannot be predicted precisely, they are thought to be inversely related to the growth rate. The increase in non-repayable loans during periods of recession will increase the total risk of the banking system and carry the crisis potential. On the other hand, chronic current account deficits are known to be a major problem for emerging economies. Current account shocks may cause a bottleneck in the national banking system. Thus, either directly or under the twin crisis hypothesis framework, it has the potential to lead to a currency crisis followed by a banking crisis. Therefore, it is believed that the current account will negatively affect crises. If there is a current account surplus, there will be no stress on the banking system, only the current account deficit will have such a consequence.

In the light of these explanations, the variables involved in the model and possible interaction with banking crises are expressed in the closed function below.

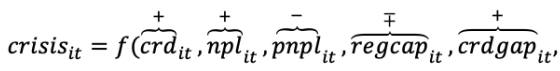

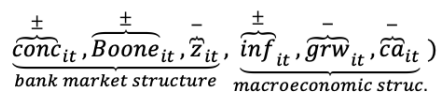

The variables in equation (3) form the $\mathrm{x}_{\mathrm{it}}$ vector in equation (1). The system of equations taking place from equations (1) and (2) will be estimated by including the specified independent variables. 


\section{Data set}

The study analyzes the data from 23 countries that entered the emerging market index of the Morgan Stanley International Capital Group (Morgan Stanley and Capital Group International / MSCI). The main reason for the institution to consider these countries in index calculation is that they offer significant investment opportunities with high growth rates and relatively low risk. In addition, despite the problems of high inflation, chronic current account deficit and dependence on foreign capital, it was accepted that they were different from other developing countries due to their reasonable performance during the 2008 global crisis period. This list of countries is presented in Annex Table 1. In the sample, there are annual data covering the 1998-2015 period of the 23 countries and the total number of observations is 4692 . The definitions of the variables included in the analysis and the data sources are presented in Table 1

In Table 2, some descriptive statistics are presented for the whole sample, while in Table 3 , country- specific summary statistics are presented.

On average, most banking crisis occurred in Russia during the sampling period. Median values vary according to the country and variable. For example, in Pakistan and Egypt for npl, in Mexico, Colombia and Peru for pnlp, in United Arab Emirates, Indonesia, Turkey and Russia for krd, have higher median values. Similarly, in Check Republic and China for crdgap, in Turkey for boone, in United Arab Emirates, Quatar and China for z score, in Russia and Egypt for inf, in China, India and Quatar for grw, in Quatar and Malaysia for ca, have higher median values.

Crdgap is considered as one of the best predictors of bank crises (Antunes et al., 2018). In the Czech Republic, China and Indonesia, this variable gave higher positive values. On the other hand, it is seen that it has a negative value in many countries such as United Arab Emirates and Thailand.

\section{Findings}

Both panel probit and dynamic panel probit methods were used in the analyses. First, (1) is estimated by the panel probit method. Then, the system of equations from (1) and (2) is estimated using the Heckit estimator and the Gauss-Hermite quadrature (ML + Gauss-Hermite quadrature) method. In the forecasting process, models with all variables are estimated first, then the meaningless variables are eliminated in order and only predictions with significant coefficients are reached. Estimation results, including both all variables and showing only significant coefficient values, are presented in Table 3, respectively. In this framework, estimates (1.2) and (2.2) are the most successful ones. 
Table 1

Definitions of Variables and the Data Sources

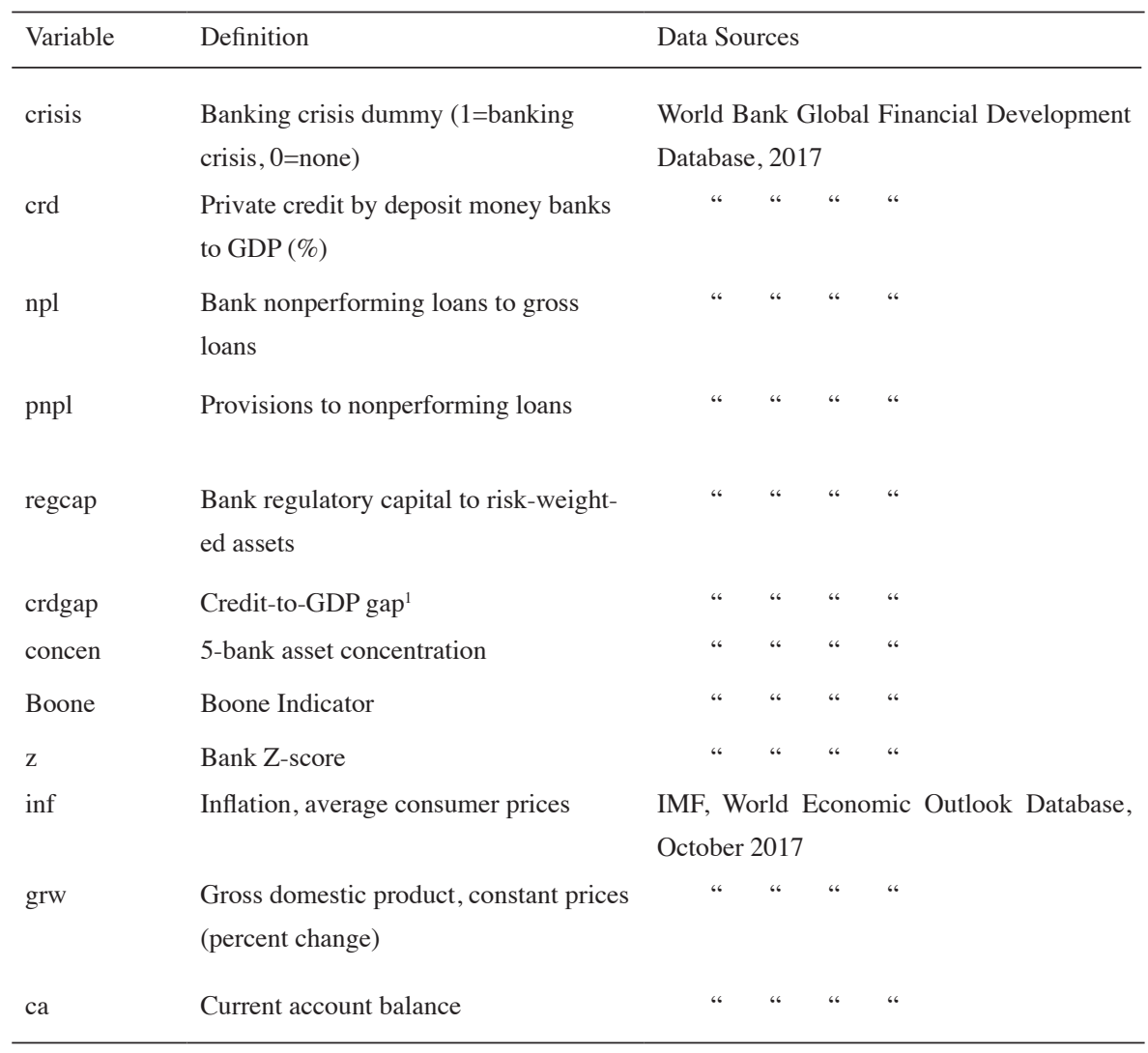

Source: World Bank Global Financial Development Database, 2017 and IMF, World Economic Outlook Database, October 2017.

(1) The ratio of credit (extended to the private sector by banks) to GDP deviation from its Hodrick-Prescott trend.

In the dynamic model estimates, the instruments used as variables are credits, non-performing loans, provisions allocated to them, credit gap and mandatory capital. All instrumental variables appear to produce significant coefficient values. In addition, covariance matrix parameters $\theta$ and $\sigma$ gave significant coefficient values.

Wald test results show that the joint significance of explanatory variables is high in all estimates. This test, in the dynamic panel probit model estimates, only reflects the significance of the explanatory variables in the main equation. 
Table 2

Descriptive Statistics

\begin{tabular}{llllll}
\hline & Mean & Std. Dev. & Min & Median & Max \\
\hline crisis & 0.0894 & 0.2856 & 0.00 & 0.00 & 1.00 \\
npl & 7.4711 & 7.5429 & 0.00 & 5.25 & 48.60 \\
pnpl & 77.2884 & 49.9924 & 0.00 & 73.57 & 282.72 \\
regcap & 13.9366 & 4.4519 & 0.00 & 13.94 & 30.90 \\
crd & 50.8632 & 32.4072 & 0.00 & 49.52 & 165.86 \\
crdgap & 0.0000 & 4.8797 & -17.41 & -0.17 & 26.14 \\
concen & 68.0086 & 22.8856 & 0.00 & 68.49 & 100.00 \\
boone & -0.0368 & 0.1889 & -1.02 & -0.04 & 2.18 \\
z & 12.0940 & 8.8989 & -2.71 & 11.69 & 93.74 \\
inf & 6.1652 & 8.8562 & -4.88 & 4.73 & 85.74 \\
grw & 4.3032 & 3.9436 & -13.13 & 4.58 & 26.17 \\
ca & 0.9047 & 6.7574 & -21.07 & 0.64 & 33.19 \\
\hline
\end{tabular}

Source: Calculated by us using data from World Bank Global Financial Development Database, 2017 and IMF, World Economic Outlook Database, October 2017.

When estimating results are examined, it is seen that both estimation approaches produce significantly different results. It is worth noting that although some variables, such as credit gap, z score and constant, produce significant coefficients in alternative estimation methods, their signs are different. In general terms, it can be said that the prediction results of the dynamic model are more consistent with the theoretical assumptions. In addition, this approach is more comprehensive and accurate than the panel probit estimates because it reflects the dynamic effects of the dependent variable. Therefore, only the estimation results of the dynamic model are focussed and studied.

Banking crises are positively affected by their past values, i.e. they have a strong persistence. Contrary to expectations, it has not been determined that credits and non-performing loans have a significant effect on banking crises. Instead, provisions for non-performing loans allocated by banks and credit gap as a systemic risk indicator appear to produce meaningful coefficient 
values. As expected, it was observed that the provisions of non-performing loans negatively and credit gap positively affect the crisis. Therefore, it is prudent behaviour to adopt a useful loan loss provisioning to increase the robustness of the bank. On the other hand, it is quite reasonable to reach the conclusion that the increase in the credit gap, which is regarded as a leading indicator of systemic risks, contributes to the increase of the probability of a crisis.

Golemi (2015), Antunes et al. (2018), Alessi and Detken (2018) emphasize the importance of credit gap as a leading indicator reflecting bank crises in recent experimental studies. Golemi (2015), Alessi and Detken (2018) stated that unsustainable credit developments lead to the accumulation of systemic risks in terms of financial stability. In this regard, Antunes et al. (2018), Alessi and Detken (2018) have developed alternative early warning models. In addition to some other variables, the credit gap was included in both models.

Credit gap is a much more successful early warning indicator than asset prices or banking sector performance instruments. This variable is particularly high in determining the use of past high leverage (Alessi and Detken, 2018). However, it is also stated that there are some shortcomings such as giving false signals in real-time. Both Golemi (2018) and Alessi and Detken (2018) emphasize that the credit gap can be used in early warning models, however, they also state that the intervention of possible crises may be late and costly due to the delayed results of this variable. Therefore, other crisis determinants should be taken into consideration together with the variables.

In our study, consistent with Alessi and Detken (2018), Antunes et al. (2018), it was determined that both the delayed dependent variable and the credit gap explain the bank crises. However, it could not be determined that credit growth has a significant effect on crises. On the other hand, it was determined that some of the variables such as nonperforming loans, their provisions, $\mathrm{z}$ score and current account deficit, which were not taken into consideration in the mentioned studies, explained the crises.

It has been determined that the control variables, $\mathrm{z}$ score, and the current account balance affect the crises. The $\mathrm{z}$ score, which reflects the financial soundness of banks, is negatively related to crises, as expected. In a banking system where robust banks take place, the probability of a crisis will naturally diminish. The negative effect of the current account deficit on bank crises suggests that the probability of crisis falls when the current account runs a surplus and this probability increases as the current account deficit grows. The countries in our sample are highly sensitive to current account balances. Despite their different economic structures, countries are quite similar in terms of fighting the current account deficit. As the current account deficit increases, the likelihood of a bank crisis, within the twin crisis hypothesis, following a currency crisis will rise. On the contrary, when the current account balance is reached or deficit is at a sustainable level, the likelihood of such countries to enter a banking crisis will be low. 


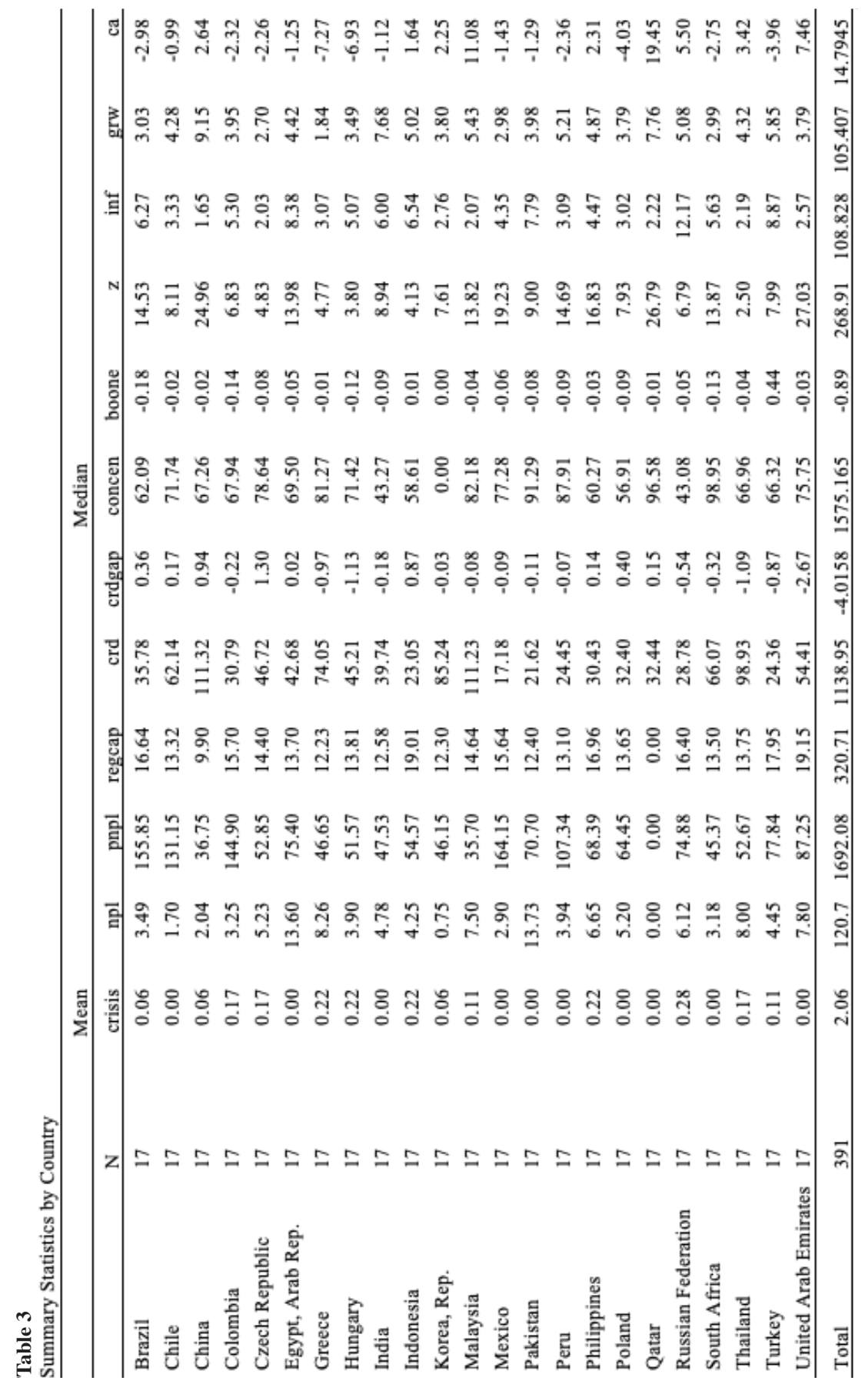




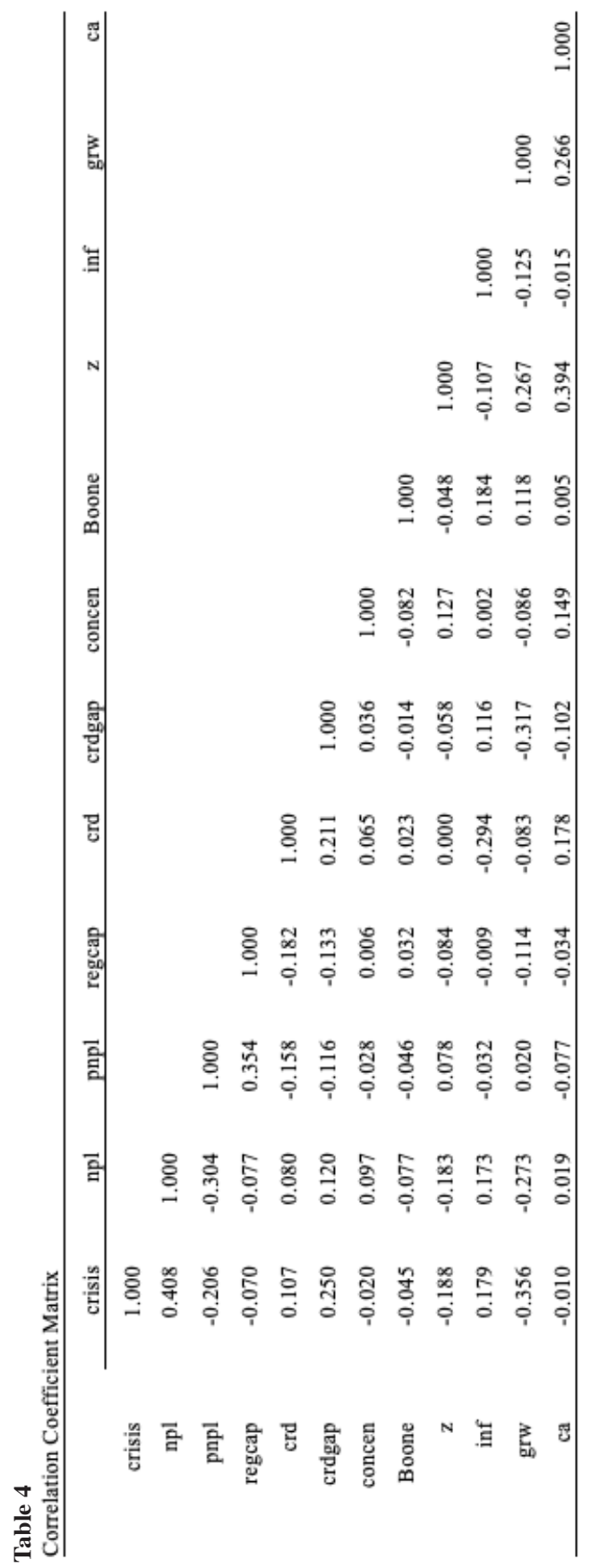


Table 5

Descriptive Statistics

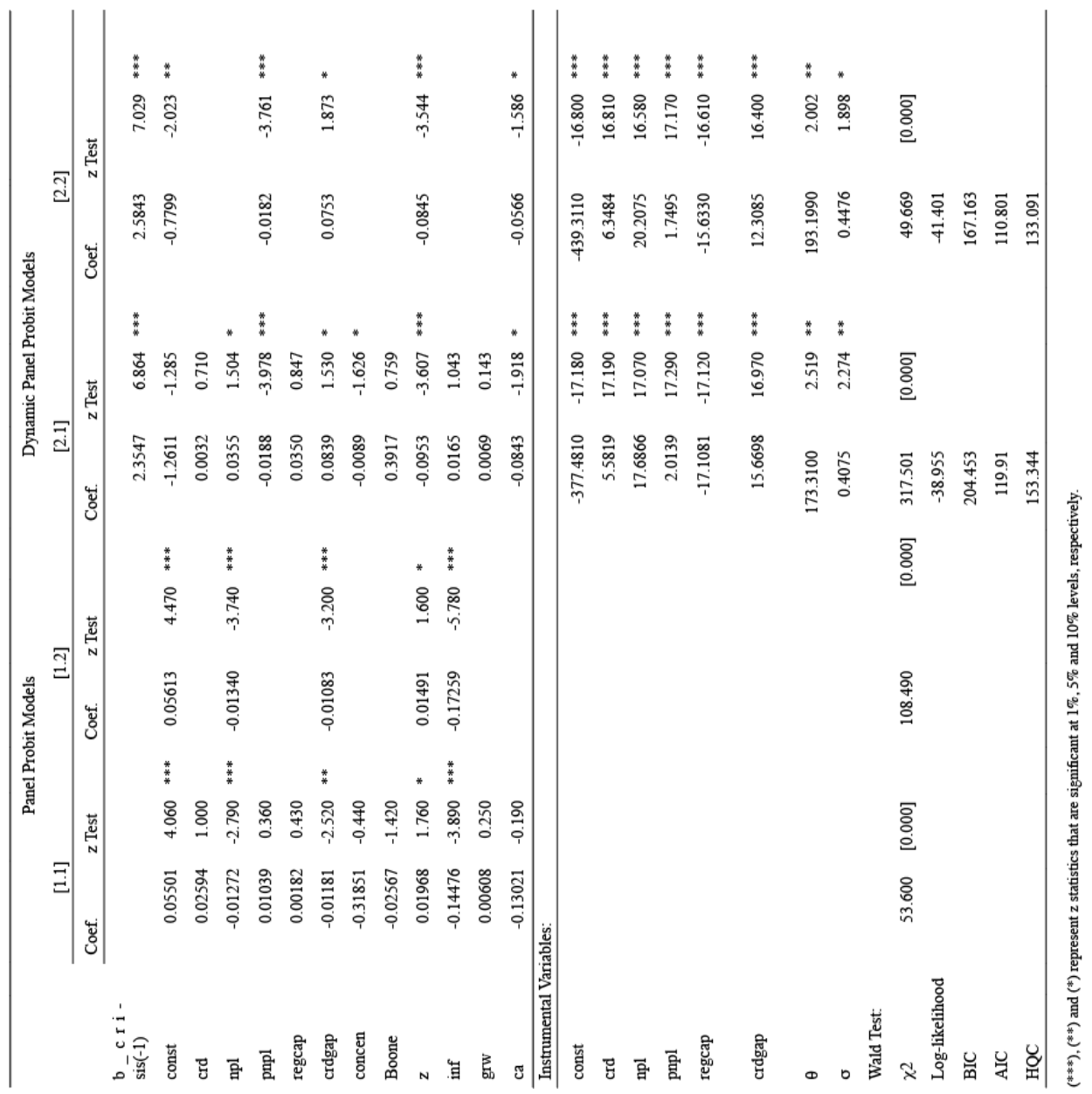


In this study, we mainly focused on the banking crisis in emerging economies. However, for bank crises in developed economies, Alessi and Detken (2018) and Antunes et al. (2018) give important clues. These studies analyze European countries for different periods and most of the countries examined are developed countries. It is seen that bank crises are further explained by a number of other variables such as credit growth, credit gap, stock prices, debt service ratio, and housing price index. Their findings show that credit growth and credit gap strongly explain bank crises.

\section{Conclusion}

The effects of credit-based variables on bank crises in the emerging 23 economies were investigated. In particular, the effects of credits and non-performing on crises are focussed. Additionally, bank system-specific and macroeconomic control variables are included in the analysis. Findings show that private sector lending by banks and non-performing loans reflecting credit risk do not explain bank crises. Instead, it has been determined that the provisions for non-performing loans by banks and the credit gap that is considered to reflect the systemic risk in the banking system affect crises.

According to findings, as the provisions for non-performing loans are increased, the stability of the banking system increases and the probability of crisis decreases. On the other hand, an escalation in the level of credit gap - a sign of systemic risk-increases the likelihood of a crisis. Furthermore, in recent experimental studies, the credit gap has been used as a leading indicator for both banking crisis and in early warning models for developed countries.

The $\mathrm{z}$ score, which is included in the analysis as a control variable and shows the financial robustness of the banks, is also in negative relation with the crises. This means that as the financial strength of banks increases, the likelihood of crisis falls. The emerging economies in the sample are quite similar in terms of the high current account deficit problem despite their different economic structures and growth approaches. For this reason, it is clear that the increase in current account deficits, though indirectly increased the probability of a banking crisis in the context of the twin deficit hypothesis.

Findings clearly show the importance of policies to offset systemic risk and a provisioning mechanism that will balance the non-performing loans in emerging economies. In addition, the financial structures of banks should be closely monitored and strengthened. This implies the importance of high capital adequacy. On the other hand, the sustainability of the current account deficit in such countries, which are largely dependent on foreign capital, is an important factor that should be taken into consideration in terms of the stability of the banking system against crises.

Lastly, for both developed and emerging economies, credit-based variables can be considered as leading indicators or determinants of possible bank crises. 


\section{References}

Alessi, Lucia and Detken, Carsten. (2018). "Identifying excessive credit growth and leverage", Journal of Financial Stability, 35(C), pp. 215-225. https://doi.org/10.1016/j.jfs.2017.06.005

Anderson, T. W. and Hsiao, Cheng. (1982). "Formulation and Estimation of Dynamic Models Using Panel Data", Journal of Econometrics, 18, pp. 47-82. https://doi.org/10.1016/0304-4076(82)90095-1

Antunes, Antonio, Bonfirm, Diana, Monterio, Nuno and Rodrigues, Paulo M.M. (2016). "Forecasting Banking Crises with Dynamic Panel Probit Models", Banco de Portugal Working Papers, No. 2016-13, August. Available from: https://www.bportugal.pt/sites/default/files/anexos/papers/wp201613.pdf

Antunes, Antonio, Bonfirm, Diana, Monterio, Nuno and Rodrigues, Paulo M.M. (2018). "Forecasting Banking Crises with Dynamic Panel Probit Models", International Journal of Forecasting, 34(2), pp. 249-275. https:// doi.org/10.1016/j.ijforecast.2017.12.003

Arellano, Manuel and Bond, Stephen. (1991). "Some Tests of Specification for Panel Data: Monte Carlo Evidence and An Application to Employment Equations", Review of Economic Studies, 58, pp. 277-297. Available from: http://people.stern.nyu.edu/wgreene/Lugano2013/pg/Arellano-Bond.pdf

Arellano, Manuel, and Bover, Olympia. (1995). "Another Look at the Instrumental Variables Estimation of Error-Component Models", Journal of Econometrics, 68, pp. 29-51. https://doi.org/10.1016/0304-4076(94)01642-D

Arellano, Manuel. (1989). “A Note on the Anderson-Hsiao Estimator for Panel Data”, Economics Letters, 31, 337-341. https://doi.org/10.1016/0165-1765(89)90025-6.

Arellano, Manuel. (2003). "Discrete choices with panel data", Investigaciones Economicas, 27(3), pp. 423-458. Available from: https://ideas.repec.org/a/iec/inveco/v27y2003i3p423-458.html

Baltagi, Badi, H. (2005). Econometric Analysis of Panel Data, (3rd Ed.). West Sussex: England, John Wiley \& Sons, Ltd. Baltagi, Badi H. and Kao, Chihwa. (2000). "Nonstationary Panels, Cointegration in Panels and Dynamic Panels: A Survey", in Advanced in Econometrics Volume 15: Nonstationary Panels, Panel Cointegration, and Dynamic Panels, Editor Badi H. Baltagi, New York, Elsevier Science Inc., pp. 7-51.

Beck, R., Jakubik, P. and Piloiu, A. (2015). Key Determinants of Non-performing Loans: New Evidence from a Global Sample. Open Economic Review 26 (3): 525-550. Available from: https://link.springer.com/article/10.1007/s11079-015-9358-8

BIS Quarterly Report (2014). International banking and financial market developments The credit-to-GDP gap and countercyclical capital buffers: questions and answers.55-70. Available from: https://www.bis.org/publ/ qtrpdf/r_qt1403.pdf

Blundell, Rcihard, Bond, Stephen, and Windmeijer, Frank. (2000). "Estimation in Dynamic $\quad$ Panel Data Models: Improving on the Performance of the Standard GMM Estimator", in Advanced in Econometrics Volume 15: Nonstationary Panels, Panel Cointegration, and Dynamic Panels, Editor Badi H. Baltagi, New York, Elsevier Science Inc., pp. 53-91.

Blundell, Richard W., and Bond, Stephen. (1998). "Initial Conditions and Moment Restrictions in Dynamic Panel Data Models", Journal of Econometrics, 87, pp. 115-143. https://doi.org/10.1016/S0304-4076(98)00009-8 
Davis, S. J.et.all. (2016). A Credit booms, banking crises, and the current account. Journal of International Money and Finance, (60):360-377. Available from: https://www.sciencedirect.com/journal/journal-of-international-money-and-finance/vol/60/suppl/C

Dell'Ariccia, G. and Marquez, R. (2006). Lending Booms and Lending Standards. The Journal of Finance 61 (5): 2511-2546. Available from: https://www.jstor.org/stable/3874718.

Ehreke, Ilka, Crastes dit Sourd, Romain, Beck, Matthew, Hess, Stephane, Axhausen, Kay W., Holz-Rau, Christian, and Scheiner, Joachim. (2016). "A Dynamic Approach to Long-term Mobility Decisions in the Life Course", ETH Zürich Research Collection, Conference Paper. https://doi.org/10.3929/ethz-b-000102844.

Elekdag, S.and Wu, Y. (2013). Rapid Credit Growth in Emerging Markets: Boon or Boom-Bust? Emerging Markets Finance and Trade 49 (5): 45-62. http://dx.doi.org/10.2753/REE1540-496X490503.

Fofack, H. (2005). Non-performing Loans in Sub-Saharan Africa: Causal Analysis and Macroeconomic Implications. World Bank Policy Research Working Paper 3769. Available from: http://documents.worldbank.org/curated/ en/446961468104639856/pdf/wps3769.pdf

Gourinchas, P. O., et.all.(2001). Lending booms: Latin America and the world. Economia, Journal of Latin American and Caribbean Economic Association 1 (2) :4799. Available from: http://economia.lacea.org/contents.htm

Ghosh, A. (2015). Banking-industry specific and regional economic determinants of non-performing loans: Evidence from US states. J. Econ.Fin. Stability. (20):93-104. https://doi.org/10.1016/j.jfs.2015.08.004.

Golemi, Ela. (2015). “Excessive Credit Growth - An Early Indicator of Financial Instability”, European Journal of Economics and Business Studies Articles, 1(2), pp. 174-179. https://dx.doi.org/10.26417/ejes.v2i1.p174-179.

Heckman, J. J. (1981). "The Incidental Parameters Problem and the Problem of Initial Conditions in Estimating a Discrete Time - Discrete Data Stochastic Process", in C.F. Manski and D. McFadden (eds.) Structural Analysis of Discrete Data with Econometric Applications. Cambridge: MIT Press, 179-195.

Hyslop, Dean R. (1999). "State dependence, serial correlation and heterogeneity in intertemporal labor force participation of married women", Econometrica 67(6), 1255-1294. Available from: https://www.jstor.org/stable/2999562.

IMF World Economic Outlook (2004). Are Credit Booms in Emerging Markets a Concern? Chapter IV. 152-153. Available from: https://www.imf.org/en/Publications/WEO/Issues/2016/12/31/Advancing-Structural-Reforms Jimenez, G. and Saurina, J. (2006). Credit cycles, credit risk, and prudential regulation. International Journal of National Banking 2(2):65-98. Available from: https://www.ijcb.org/journal/ijcb06q2a3.htm

Jordà, Ò. et.all. (2011). Financial crises, credit booms, and external imbalances: 140 years of lessons IMF Economic Review 59 (2): 340-378. https://doi.org/10.1057/imfer.2011.8

Kano, Shigeki. (2013). "Nonlinear Simultaneous Equations Approach for Panel Markov Dynamic Probit Models with Unrestricted Error Covariance", Osaka Prefecture University, Discussion Paper New Series, No. 2013-6, September. Available from: https://pdfs.semanticscholar.org/1b52/8fd9b280f3e26c4b2914314fa6ff00683e6f. pdf?_ga=2.133131726.1700451067.1572326858-1648334992.1572326858

Keane, Michael P. and Sauer, Robert M. (2010). "A computationally practical simulation estimation algorithm for dynamic panel data models with unobserved endogenous state variables", International Economic Review, 51(4), pp. 925-958. https://doi.org/10.1111/j.1468-2354.2010.00606.x 
Keane, Michael P. and Sauer, Robert M. (2009). "Classification error in dynamic discrete choice models: Implications for female labor supply behavior", Econometrica, 77(3), pp. 975-991. https://doi.org/10.3982/ECTA7642

Keane, Michael P. (1994). “A computationally practical simulation estimator for panel data”. Econometrica 62(1), 95-116. DOI: $10.2307 / 2951477$

Keeton, W. and C. Morris. (1987). Why Do Banks' Loan Losses Differ? Federal Reserve Bank of Kansas City Economic Review. May. 3-21. Available from: https://www.kansascityfed.org/ /media/files/publicat/econrev/ econrevarchive/1987/2q87keet.pdf

Lang, J. H and Welz, P. (2017). Measuring credit gaps for macroprudential policy. ECB Financial Stability Review. Special Features. Available from: https://www.ecb.europa.eu/pub/pdf/fsr/financialstabilityreview201705. en.pdf?93eee057f5eef9e411a83a729fd0822d

Levine, R. (2005). Finance and growth: theory and evidence. Handbook of Economic Growth. Elsevier. Chapter 12. 865-934. https://doi.org/10.1016/S1574-0684(05)01012-9

Liesenfeld, Roman, valle Moura, Guilherme, and Richard, Jean-Francois. (2007). "Dynamic Panel Probit Models for Current Account Reversals and Their Efficient Estimation”, SSRN Papers, No. 998770. https://dx.doi. org/10.2139/ssrn. 988770

Louzis, D. P., Vouldis, A.T. and Metaxas, V.L. (2010). Macroeconomic and bank-specific determinants of nonperforming loans in Greece: a comparative study of mortgage, business and consumer loan portfolios. Bank of Greece Working Paper 118. https://dx.doi.org/10.2139/ssrn.1703026

Messai, A. (2013). Micro and macro determinant of non-performing loans. Int.J. Econ .Fin. Iss. 3(4): 852-860. Available from: http://www.econjournals.com/index.php/ijefi/article/view/517

Miranda, A. (2007). Dynamic Probit Models for Panel Data: A Comparison of Three Methods of Estimation.UK Stata Users Group Meeting, September 10. Available from: https://www.stata.com/meeting/13uk/miranda_Dprob_pe.pdf

Ozili, P.K.(2015). How bank managers anticpate non-performing loans : Evidence from Europe, US, Asia and Africa.. J.App.Fin.Acc. 1(2):73-80. https://doi.org/10.11114/afa.v1i2.880

Ranjan, R. and Dahl, S.C. (2003). Non-performing Loans and Terms of Credit of Public Sector Banks in India: An Empirical Assessment. Reserve Bank of India Occasional Papers 24 (3). Available from: https://rbidocs.rbi.org. in/rdocs/Publications/PDFs/60613.pdf

Salas, V. and Saurina, J. (2002). Credit Risk in Two Institutional Regimes: Spanish Commercial and Savings Banks. Journal of Financial Services Research, 22(3): 203-224. https://doi.org/10.1023/A:1019781109676

Schularick ,M. and Taylor, A.M. (2009) Credit Booms Gone Bust: Monetary Policy, Leverage Cycles and Financial Crisis, 1870-2008. Nber working Paper No.15512. Available from: https://www.nber.org/papers/w15512.pdf 
K. B Tunay, et al. / Contaduría y Administración 65(1) 2020, 1-21

http://dx.doi.org/10.22201/fca.24488410e.2020.2215

\section{Annex}

Table A1

Countries in the Sample

\begin{tabular}{ll}
\hline Brazil & Mexico \\
Chile & Pakistan \\
China & Peru \\
Colombia & Philippines \\
Czech Republic & Poland \\
Egypt, Arab Rep. & Qatar \\
Greece & Russian Federation \\
Hungary & South Africa \\
India & Thailand \\
Indonesia & Turkey \\
Korea, Rep. & United Arab Emirates \\
Malaysia & \\
\hline
\end{tabular}

Source: Morgan Stanley and Capital Group International (MSCI) 